\title{
Theoretical and practical aspects of basic soil treatment in the conditions of modern soil management systems in Russia
}

\author{
Alexey Belenkov, Mikhail Mazirov, Valeria Arefieva *
}

Department of Soil Management and Experimental Design, Russian State Agrarian University - Moscow Timiryazev Agricultural Academy, Moscow, Russia

\section{Article Info}

Received : 15.03 .2018 Accepted : 10.07 .2018

\begin{abstract}
The questions of inserting and implementing the different methods of basic soil treatment in the different crop plantings in the conditions of steppe zone in Nizhnee Povolzhye and Central Part of Non-chernozem Belt of the Russian Federation are analyzed. Systemize and complex research of the above questions are caused by multivalued opinions of agrarian scientists that are involved in the practical aspects of agrarian production towards them. On the results of long term researches is defined that the most effective and practice in cereal crop rotations are the basic soil management systems combining the different methods of tillage, mini-till and no-till soil treatment along with usage of modern machines and aggregates. In the conditions of field experiment at Centre of Precision Farming of Russian State Agrarian University - Moscow Timiryazev Agricultural Academy, along with the others, the tasks on economic efficiency and ecological safety that are the basis of precision farming concept are being solved.

Keywords: Soil treatment methods, tillage, no-tillage, mini-till, no-till, resource saving, soil management system, crop rotation, combined soil treatment, regions of the Russian Federation.
\end{abstract}

(C) 2018 Federation of Eurasian Soil Science Societies. All rights reserved

\section{Introduction}

Soil treatment is most energy and fund consuming process in agrarian production. Treatment of one soil hectare demands $18-320$ kilowatt-hour or $50-80 \mathrm{~kg}$ of fuel. Soil treatment along with the positive effect influenced negatively on the fertility, e.g., using the heavy tractors and units increases the density of arable and sub-arable soil layers. The frequent loosening treatments along with activation of biological processes and mineralization of organic matter cause the significant loses of accessible nitrogen, decrease the humus content and development of erosion processes. In this regard, developing the most economical soil treatment technologies that provide effective decreasing the energy expenduteres is the important condition for modern soil management. The high level of soil treatment intensification (systematic fertilizing and implementing the herbicides and ameliorants) caused changing in function of soil treatment and decreasing its determination of crop yield up to 8- $12 \%$. The above processes are characterizing the soils with high potential level of fertility and favorable agrophysical characteristics for crop development. In the above conditions the soil treatment could be minimalized and used only for fertilizing, implementing the ameliorants and herbicides, etc. The main task is aimed to maintaining soil fertility, regulation of water and air conditions, erosion protection (Belenkov et at., 2015).

Nowadays the soil treatment is not considered as predictably consuming and not progressing link of soil treatment system. Soil treatment became much more mobile and dynamic in its development. The theoretical and practical aspects of soil treatment both for the separate crops and in crops rotations point out the new

\footnotetext{
${ }^{*}$ Corresponding author.

Department of Soil Management and Experimental Design, Russian State Agrarian University - Moscow Timiryazev Agricultural Academy, Timiryazevskaya Str., 49, Moscow, 127550, Russia

Tel.: + 74999761642

e-ISSN: 2147-4249 DOI: $10.18393 /$ ejss.448593
} 
approaches of solving the important question of economizing the materials and funds that, in its turn, causes increasing the crop yield and stabilization of soil fertility. Soil treatment, along with crops rotation, is the most significant link of soil treatment system due to defining its intensity and consuming level, level of anthropogenic load, soil resistance to erosion, the characteristics of machines and tools using in agrotechnologies.

\section{Material and Methods}

In field experiments carried out at the end of XX century - at the beginning of XXI century in chernozem drysteppe and semi-arid zones of Volgograd region the variants of terms, treatments and depths of implementing permanent and combined basic autumn and early spring soil treatment for separate crops and in the system of crops rotations were searched.

In the field experiment No1 carried out in the experimental farm "Gornaya Polyana" at Volgograd State Agrarian University and in the farm "Tingutinsky" in Svetloyarsk district of Volgogard region in the period of 1986-1989 in crops rotation fallow - winter wheat - barley the following variants of the basic soil treatment at $25-27 \mathrm{~cm}$ were studied:

1. mouldboard ploughing;

2. subsurface loosing;

3. treatment by pillars;

4. chisel treatment.

In the field experiment No 2 carried out in the experimental farm "Gornaya Polyana" at Volgograd State Agrarian University in the period of 1989-1993 in crops rotation fallow - winter wheat (kernel) - sorgo (kernel) - barley the following variants of the basic soil treatment were studied:

1. mouldboard ploughing at $25-27 \mathrm{~cm}$ for all crops;

2. pillar treatment at $25-27 \mathrm{~cm}$ for winter wheat - mouldboard ploughing at $25-27 \mathrm{~cm}$ for sorgo - pillar treatment at 25- $27 \mathrm{~cm}$ for barley;

3. pillar treatment at $20-22 \mathrm{~cm}$ for winter wheat - mouldboard ploughing at $25-27 \mathrm{~cm}$ for sorgo - pillar treatment at 20 - $22 \mathrm{~cm}$ for barley;

4. pillar treatment at $12-14 \mathrm{~cm}$ for winter wheat - mouldboard ploughing at $25-27 \mathrm{~cm}$ for sorgo - pillar treatment at $12-14 \mathrm{~cm}$ for barley.

In the field experiment No 3 carried out in JSC "Gelio Park-Agro" in Mikhaylovsky district of Volgograd region in the period of 2000-2003 in the conditions of southern chernozem soil in crops rotation fallow winter wheat - spring wheat - barley the following variants of the basic soil treatment were studied:

1. mouldboard ploughing;

2. subsurface loosing;

3. pillar treatment, $1,2,3$ - at $25-27 \mathrm{~cm}$;

4. ripper disk treatment;

5. combined treatment, 5,6 - at $10-12 \mathrm{~cm}$ for all crops.

The shallow soil treatments at 10-12 cm of depth for spring wheat during the spring season were implemented:

1. ripper disk treatment;

2. combined treatment;

3. rod cultivator treatment.

In field experiment № 4 carried out in the period of 2000-2003 in Nighne-Volghsky Research Institute of Agriculture the following variants of the basic autumn soil treatment for fallow as predecessor of winter wheat were studied:

1. mouldboard ploughing at $25-27 \mathrm{~cm}$ in spring for early fallow;

2. mouldboard ploughing at $25-27 \mathrm{~cm}$;

3. cultivator treatment at $12-14 \mathrm{~cm}$;

4. combined treatment at $12-14 \mathrm{~cm}$;

5. ripper disk treatment at $8-10 \mathrm{~cm}$;

6. cultivator treatment at $8-10 \mathrm{~cm}$.

In industrial experiment №5 carried out in the period of 2000-2003 in JSC "Sovkhoz "Karpovsky" in Gorodischensky district of Volgograd region in crops rotation fallow - winter wheat - barley the following variants of the basic soil treatment were studied: 
1. mouldboard ploughing in autumn at $25-27 \mathrm{~cm}$ for fallow along with soil treatment in spring;

2. pillar treatment at $25-27 \mathrm{~cm}$ for barley along with soil treatment in spring;

3. ripper disk treatment at $8-10 \mathrm{~cm}$;

4. cultivator treatment at $12-14 \mathrm{~cm}$;

5. combined treatment at $12-14 \mathrm{~cm}$.

In field experiment №6 carried out in the period of 2007-2009 in the experimental farm of Vocational School No 56 in Pallasovsky district of Volgograd region in crops rotation fallow - spring wheat - barley the following variants of the basic soil treatment were studied:

1, 2. mouldboard ploughing at $20-22 \mathrm{~cm}$ and subsurface loosing at $20-22 \mathrm{~cm}$ for spring wheat and barley;

3. mouldboard ploughing at $20-22 \mathrm{~cm}$ for spring wheat and subsurface loosing at $12-14 \mathrm{~cm}$ for barley;

4. subsurface loosing at $20-22 \mathrm{~cm}$ for spring wheat and mouldboard ploughing at $12-14 \mathrm{~cm}$ for barley;

5. mouldboard ploughing at 20-22 cm for spring wheat and null treatment (sowing without soil treatment) for barley;

6. scuffling treatment at $8-10 \mathrm{~cm}$ in spring for fallow and subsurface loosing at 20-22 in autumn for barley (Belenkov, 2010).

In the field experiment of Centre of Precision Farming at Russian State Agrarian University - Moscow Timiryazev Agricultural Academy during recent 10 years, starting from 2009, in the conditions of sod-podzol soil the comparison of 1- mouldboard ploughing, 2 -Mini-till and 3 - No-Till soil treatments in cereal and tilling crops rotation: vetch and oat feeding mixture - winter wheat with reap mustard for siderite - potato barley were carried out (Balabanov et al., 2013).

\section{Results}

The yield of cereal crops obtained during the researches in the period of 1986-1989 performed in Table 1. Variants of basic soil treatment - ploughing, subsurface and pillar treatment - was practically equal on the yield; chisel treatment performed the decreased yield.

Table 1. Results of the field experiments on searching the basic soil treatments in farm crops rotations in Volgogard region

\begin{tabular}{ccccc}
\hline Basic soil treatment & $\begin{array}{c}\text { Crop yield } \\
\text { in crops rotation, } \\
\text { tha }\end{array}$ & $\begin{array}{c}\text { Profitability, } \\
\%\end{array}$ & $\begin{array}{c}\text { Energy } \\
\text { efficiency } \\
\text { coefficient }\end{array}$ & $\begin{array}{c}\text { Soil humus } \\
\text { balance, } \\
\text { t-ha }\end{array}$ \\
\hline
\end{tabular}

Field experiment No1. Experimental farm "Gornaya Polyana" at Volgograd State Agrarian University and farm "Tingutinsky" in Svetloyarsk district (1986-1989)

\begin{tabular}{lllll}
\hline Ploughing at $25-27 \mathrm{~cm}$ & 1.22 & 72.6 & 2.12 & -2.4 \\
Subsurface cultivator treatment at $25-27 \mathrm{~cm}$ & 1.23 & 84.0 & 2.12 & -2.4 \\
Chisel ploughing at $25-27 \mathrm{~cm}$ & 0.97 & 76.9 & 2.07 & -2.6 \\
Pillar treatment at $25-27 \mathrm{~cm}$ & 1.21 & 48.5 & 1.65 & -2.3
\end{tabular}

\begin{tabular}{lcccc}
\hline \multicolumn{4}{c}{ Field experiment No 2. Experimental farm “Gornaya Polyana” at Volgograd State Agrarian University (1989-1993) } \\
\hline P 25 - P 25 - P 25* & 1.96 & 99.4 & 2.97 & -1.7 \\
Pl 25 - Pl 25 - Pl 25 & 1.95 & 104.4 & 3.07 & -1.7 \\
Pl 20 - P 25 - Pl 20 & 1.97 & 108.2 & 3.15 & -1.6 \\
Pl 12 - P 25 - Pl 12 & 1.91 & 105.6 & 3.13 & -1.4 \\
\hline
\end{tabular}

* - P, Pl - mouldboard ploughing, pillar treatment; 12, 20, 25 - at 12-14, 20-22, 25-27 cm: in crops rotation fallow winter wheat - sorgo (kernel) - barley

Defect of chisel treatment with chisel plough is not complete loosing of the soil surface with the widely arranged tools. While chisel treatment the intrasoil consolidated ridges are left between the passes of tool that is the arable soil layer is treated within the passes only. This construction defect causes aggravating the water and mechanical soil properties and nutrition regime of crops, decreasing the crop and soil weeding and, as the result, the crop yield. Variant of chisel treatment is less energetically and economically effective in comparison with the other variants of basic soil treatment. Results of the field experiment No 2 in the period of 1989-1993 are presented in Table 2.

Variant of basic soil treatment - pillar treatment at $20-22 \mathrm{~cm}$ for winter wheat and barley with ploughing at $25-27 \mathrm{~cm}$ for sorgo (kernel) performed the increased yield.

In the conditions the southern chernozem soils the subsurface treatment at 25-27 cm performed higher economic and energy efficiency along with the equal parameters on yield in comparison with the other variants of basic soil treatment. 
Table 2. Results of the field experiments on searching the basic soil treatments in farm crops rotations in Volgogard region

\begin{tabular}{|c|c|c|c|c|}
\hline Basic soil treatment & $\begin{array}{c}\text { Crop yield } \\
\text { in crops rotation, } \\
\mathrm{t}^{\text {ha }}\end{array}$ & $\begin{array}{c}\text { Profitability, } \\
\%\end{array}$ & $\begin{array}{c}\text { Energy } \\
\text { efficiency } \\
\text { coefficient }\end{array}$ & $\begin{array}{l}\text { Soil humus } \\
\text { balance, t-ha }\end{array}$ \\
\hline \multicolumn{5}{|c|}{ Field experiment №3. JSC “Gelio Park-Agro” in Mikhaylovsky district (2000-2003) } \\
\hline \multicolumn{5}{|c|}{ Autumn season } \\
\hline Ploughing at $25-27 \mathrm{~cm}$ & 1.76 & 80.7 & 2.22 & -2.0 \\
\hline Subsurface cultivator treatment at $25-27 \mathrm{~cm}$ & 1.76 & 93.9 & 2.54 & -2.0 \\
\hline Pillar treatment at $25-27 \mathrm{~cm}$ & 1.65 & 86.7 & 2.30 & -1.9 \\
\hline Heavy ripper disk treatment at $10-12 \mathrm{~cm}$ & 1.50 & 92.6 & 2.45 & -1.7 \\
\hline Combined treatment at $10-12 \mathrm{~cm}$ & 1.64 & 96.1 & 2.58 & -1.9 \\
\hline \multicolumn{5}{|c|}{ Spring season } \\
\hline Rod cultivator treatment at $10-12 \mathrm{~cm}$ & 1.28 & 84.9 & 2.28 & -1.5 \\
\hline Heavy ripper disk treatment at $10-12 \mathrm{~cm}$ & 1.09 & 75.8 & 2.03 & -1.3 \\
\hline Combined treatment at $10-12 \mathrm{~cm}$ & 1.03 & 63.1 & 1.83 & -1.3 \\
\hline
\end{tabular}

The most effective basic soil treatment for winter wheat, spring wheat and barley in spring season was rod cultivation treatment at $10-12 \mathrm{~cm}$.

Table 3. Results of the field experiments on searching the basic soil treatments in farm crops rotations in Volgogard region

\begin{tabular}{|c|c|c|c|c|}
\hline Basic soil treatment & $\begin{array}{c}\text { Crop yield } \\
\text { in crops rotation, } \\
\text { tha }^{\text {ha }}\end{array}$ & $\begin{array}{c}\text { Profitability, } \\
\%\end{array}$ & $\begin{array}{c}\text { Energy } \\
\text { efficiency } \\
\text { coefficient }\end{array}$ & $\begin{array}{l}\text { Soil humus } \\
\text { balance, t-ha }\end{array}$ \\
\hline \multicolumn{5}{|c|}{ Field experiment No 4. Nighne-Volghsky Research Institute of Agriculture (2000-2003) } \\
\hline \multicolumn{5}{|c|}{ Autumn season } \\
\hline Ploughing at $25-27 \mathrm{~cm}$ & 1.35 & 82.6 & 2.15 & -2.7 \\
\hline \multicolumn{5}{|c|}{ Spring season } \\
\hline Ploughing at $20-22 \mathrm{~cm}$ & 1.05 & 71.5 & 2.06 & -2.5 \\
\hline Heavy ripper disk treatment at $10-12 \mathrm{~cm}$ & 1.18 & 79.3 & 2.25 & -2.5 \\
\hline Anti-erosion cultivator treatment at $12-14 \mathrm{~cm}$ & 1.26 & 78.4 & 2.20 & -2.6 \\
\hline Steam cultivator treatment at $10-12 \mathrm{~cm}$ & 1.18 & 73.2 & 2.05 & -2.5 \\
\hline Combined treatment at $12-14 \mathrm{~cm}$ & 1.20 & 75.2 & 2.11 & -2.5 \\
\hline \multicolumn{5}{|c|}{ Industrial experiment No 5. JSC "Sovkhoz "Karpovsky" in Gorodischensky district (2000-2003) } \\
\hline \multicolumn{5}{|c|}{ Autumn season } \\
\hline Ploughing at $25-27 \mathrm{~cm}$ & 1.24 & 66.9 & 1.84 & -2.7 \\
\hline Pillar unit treatment at $25-27 \mathrm{~cm}$ & 1.14 & 55.8 & 1.92 & -2.5 \\
\hline \multicolumn{5}{|c|}{ Spring season } \\
\hline Heavy ripper disk treatment at $8-10 \mathrm{~cm}$ & 0.97 & 45.3 & 1.80 & -2.2 \\
\hline Anti-erosion cultivator treatment at $12-14 \mathrm{~cm}$ & 1.02 & 52.7 & 1.95 & -2.0 \\
\hline Combined treatment at $10-12 \mathrm{~cm}$ & 1.01 & 48.0 & 1.91 & -2.0 \\
\hline
\end{tabular}

In accordance with the results obtained in field experiment in Nighne-Volghsky Research Institute of Agriculture and in industrial experiment in JSC "Sovkhoz "Karpovsky" in Gorodischensky district the antierosion treatment at 12-14 cm with cultivator along with ploughing performed the most effective results.

Table 4. Results of the field experiments on searching the basic soil treatments in farm crops rotations in Volgogard region

\begin{tabular}{|c|c|c|c|c|}
\hline Basic soil treatment & $\begin{array}{c}\text { Crop yield } \\
\text { in crops rotation, } \\
\mathrm{t}^{\text {-ha }}\end{array}$ & $\begin{array}{c}\text { Profitability, } \\
\%\end{array}$ & $\begin{array}{c}\text { Energy } \\
\text { efficiency } \\
\text { coefficient }\end{array}$ & $\begin{array}{c}\text { Soil humus } \\
\text { balance, } \\
\text { t-ha }\end{array}$ \\
\hline \multicolumn{5}{|c|}{ Field experiment № 6. Vocational School №56 in Pallasovsky district (2007-2009) } \\
\hline P20 - P20* & 0.41 & 10.65 & 1.08 & -3.3 \\
\hline S20 - S20 & 0.37 & 7.02 & 1.02 & -3.4 \\
\hline S20 - S12 & 0.36 & 7.65 & 1.03 & -3.0 \\
\hline S20 - P12 & 0.48 & 14.98 & 1.23 & -3.3 \\
\hline $\mathrm{P} 20-\ll 0 »$ & 0.30 & 5.79 & 0.94 & -2.8 \\
\hline Sc10 - S20 & 0.40 & 11.92 & 1.19 & -3.5 \\
\hline
\end{tabular}

* - P, S, Sc, «0» - mouldboard ploughing, subsurface treatment, scuffling treatment, No-Till treatment (bold shrift treatment in spring season) at 20-22, 12-14, 8-10 cm 
Results of the field experiment №6 in the period of 2007-2009 are presented in Table 6. In the conditions of Zavolghsky region among the variants of basic soil treatment the most effective results in the crops rotation performed combined soil treatment that included subsurface loosing for spring wheat at $20-22 \mathrm{~cm}$ and ploughing for barley at $12-14 \mathrm{~cm}$. It is necessary to point out in crops rotation the variant of subsurface stubble treatment for first crop combined with subsurface treatment in spring season for second crop.

In Table 5 the following results on crop yield obtained in Centre of Precision Farming at Russian State Agrarian University - Moscow Timiryazev Agricultural Academy are presented: in average for the research period in the variant of ploughing the high yield performed potato and vetch and oat feeding mixture; in variant of no-till treatment - winter wheat; barley had the equal parameters of yield for both variants of soil treatment.

Table 5. Crop yield in Centre of Precision Farming at Russian State Agrarian University - Moscow Timiryazev Agricultural Academy, tha

\begin{tabular}{|c|c|c|c|c|c|c|c|c|c|c|}
\hline \multirow[b]{2}{*}{ Basic soil treatment } & \multicolumn{10}{|c|}{ Crop yield } \\
\hline & 2009 & 2010 & 2011 & 2012 & 2013 & 2014 & 2015 & 2016 & 2017 & In average \\
\hline \multicolumn{11}{|c|}{ Vetch and oat feeding mixture } \\
\hline Mouldboard ploughing & 21.3 & 20.5 & 10.8 & 20.6 & 22.1 & 24.5 & 31.2 & 25.3 & 22.2 & 22.1 \\
\hline No-Till & 25.0 & 19.4 & 9.4 & 27.3 & 24.3 & 25.3 & 28.9 & 27.5 & 6.1 & 21.5 \\
\hline $\mathrm{LSD}_{05}$ & 3.40 & 1.08 & 2.59 & 3.10 & 2.0 & 0.83 & 3.07 & 3,10 & 5.46 & - \\
\hline \multicolumn{11}{|c|}{ Winter wheat } \\
\hline Mouldboard ploughing & 4.23 & 4.63 & 3.70 & 6.31 & 6.12 & 2.75 & 6.74 & 5.00 & 5.39 & 5.0 \\
\hline No-Till & 5.09 & 4.11 & 3.55 & 6.15 & 5.87 & 4.59 & 6.73 & 5.52 & 5.09 & 5.19 \\
\hline $\mathrm{LSD}_{05}$ & 0.23 & 0.25 & 0.23 & 0.14 & 0.19 & 1.42 & 0.11 & 0.39 & 0.24 & - \\
\hline \multicolumn{11}{|c|}{ Potato } \\
\hline Mouldboard ploughing & 41.5 & 21.7 & 24.4 & 19.9 & 28.6 & 25.1 & 31.4 & 31.0 & 24.2 & 27.5 \\
\hline Mini-Till & 37.5 & 20,7 & 23,2 & 18.3 & 25.9 & 24.6 & 26.2 & 26.7 & 20.7 & 24.9 \\
\hline $\mathrm{LSD}_{05}$ & 1.74 & 1.42 & 0.50 & 0.56 & 0.16 & 0.90 & 1.08 & 2.11 & 3.3 & - \\
\hline \multicolumn{11}{|c|}{ Barley } \\
\hline Mouldboard ploughing & 5.40 & 3.35 & 2.62 & 4.33 & 5.16 & 3.85 & 5.52 & 4.03 & 4.21 & 4.27 \\
\hline Mini-Till & 5.78 & 2.99 & 2.83 & 4.20 & 5.00 & 4.01 & 5.22 & 3.99 & 4.04 & 4.23 \\
\hline $\mathrm{LSD}_{05}$ & 0.26 & 0.21 & 0.41 & 0.90 & 0.13 & 0.17 & 0.28 & 0.19 & 0.17 & - \\
\hline
\end{tabular}

While the analysis of crop yield, it is necessary to pay attention that during the majority of the years the yield of winter wheat in variant of mouldboard ploughing exceeded the variant of No-Till treatment. Only in 2014, the yield of winter wheat in variant of mouldboard ploughing was in 1,7 times higher in comparison with No-Till treatment due to thin shoots caused by high level precipitations in autumn of 2013. In addition, in average for the period of 2009-2017 the yield of winter wheat in variant of No-Till at 0, 19 t-ha exceeds mouldboard ploughing.

The influence of mouldboard ploughing and minimum treatment on yield of barley is not equal. In half number of years, Mini-Till treatment exceeds the ploughing on yield. Only in 2015 and 2016 the variant of mouldboard ploughing performed the higher yield of barley that caused the higher average parameters of yield, but, the difference between the variants is not significant as the absolute difference was $0,03 \mathrm{t}^{\text {tha }}$ only. In a number of years number the higher yield of vetch and oat feeding mixture in variant of No-Till treatment is obtained. The above results indicate the possibility to use this mixture as fallow crop with sowing into untreated soil.

In accordance with crop physiology, potato had the higher yield in variant of moulboard ploughing. In average during the research period the yield of potato in variant of mouldboard ploughing exceeded MiniTill treatment at 2,6 t-ha (Belenkov, 2010).

\section{Discussion}

In the conditions of low level of soil management, insufficient fertilizing and implementing the crop protection chemical means, etc. the significance of soil treatment increases and is aimed to mobilization of potential soil fertility, increasing the accessibility of nutrients, maintaining the soil structure and phytosanitary situation that are favorable for crop cultivation (Belenkov, 2016).

Modern agriculture is based on implementing the new tools and machines for soil treatment that allow to a considerable extent to protect and maintain soil fertility at the appropriate level, stably increase the crop production, use natural and technogenic potential economically and efficiently. It is a high importance the ecological and energy consumption aspects of modern crop production technologies, in the first instance, 
which connected with modernization of soil treatment methods both for single crops and in crops rotation along with considering the biological characteristic of crops and resource potential of agrarian producers.

Modern soil management systems include implementing differential technologies of basic soil treatment along with considering the biological characteristic of crops, landscape conditions, weed number, climatic conditions, erosion level, including fallow in crops rotation ant the other relevant conditions (Cherkasov, 2006).

Until now, the opinions on possibility and necessity of using the mouldboard plough as a tool for basic soil treatment differ. It is necessary to underline the necessity of using the mouldboard soil treatment with the aim to create the homogeny structure of arable soil level and favorable agrophysical and microbiological parameters of soil, increase the quality of weeding and crop protection measures. The above facts of positive results the implementing of the mouldboard treatment in a significant extent allow to compensate for some negative effects connected with significant energy and fund consumption, increasing the possibility of erosion processes and soil deflation, decreasing water accumulation.

The main positive aspects of using the subsurface soil treatment are protection from soil erosion, decreasing the water accumulation especially in drought conditions, balancing the humus content, first of all, in the upper soil levels, decreasing the costs for soil treatment; the negative aspects - aggravating the phytosanitary situation, differentiation the arable level on soil fertility, restriction to proper crop residues, fertilizers and ameliorants placement and regulation of agrophysical properties of soil.

The opinion of implementing such soil treatment methods as Mini-Till, No-till treatments, sowing without treatment, etc, in the majority of the regions in Russia has not sufficient scientific basis (Shulmeister, 1995; Shukhov et al., 2011; Pleskachev et al., 2013).

In accordance with the informational resources (data of 2008), the intense mechanical soil treatment caused the following negative results:

- area of soil erosion - 42,6 mln ha, annual increase of area - 400-500 thousand ha, annual loses of soil - 15$20 \mathrm{t}^{\text {tha }}$ (loses of 2,5 cm of arable soil are equal to loses of $980 \mathrm{~kg}$ of nitrogen, $200 \mathrm{~kg}$ of phosphorus, 3500 $\mathrm{kg}$ of potassium;

- consolidating the upper soil levels. For example, in case when field area is equal to $100 \%$, the area of machine's tracks could reached up to $200-300 \%$ as the number of passes along the field is up to 20 . The soil consolidating cases the loses of crop production up to $40-60 \%$;

- intense mechanical treatment prevents increasing crop production;

- long period of implementing the moulboard soil treatment cased decreasing the initial soil fertility and humus content;

- deep mouldboard ploughing destroyed soil structure (Sheptukhov, 2009).

In this connection during the recent years the methods of subsurface soil treatment, including Mini-Till are widely implemented. Implementing of the exact method of soil treatment depends on the following factors: soil type, soil density, biological characteristics of crop. For example, the cereal crops are not requiring the deep loosening and, in this case, it is possible to implement subsurface treatment at $14-15 \mathrm{~cm}$. Implementing the subsurface treatment with preliminary scuffling of straw residues instead of mouldboard ploughing causes increasing the humus content

In the system of soil treatment without ploughing the preventive weeding starts in the period between harvesting the preceding crop and sowing the coming crop. The other effective methods of weeding without placement of weeds should be planned and implemented. The soil treatment with evenness placement of straw is effective and provoke germination of fallen kernels and weeds. The succeeding fertilizing significantly decreases the number of weeds. In accordance with the conditions, the placement of herbicide with continuity weeding effect should be implemented in 2 days before sowing or in 3-4 days after sawing but before germination of cereal crop.

Implementing Mini-Till treatments allows achieving the high yields without destroying the soil fertility due to decreasing the level of mechanical treatment and return of straw into the soil (Keller, 2001).

Covering the soil with reaped restudies depresses growing the weeds, so-called "herbicide effect" and decreases the costs for chemical weeding of crops. Annual mouldboard ploughing due to putting deeper the upper soil level causes distraction the soil microflora (aerobic microorganisms) and decreasing initial soil fertility that increases the placement of mineral fertilizers and production costs (Sdobnikov, 2000).

Nowadays No-Till system of soil treatment that assists to funds and water accumulation is widely used in many countries. But, Now-Till system and sowing without any treatment were implemented even in 6 
century BC. Uning the planting peg allowed to get the yield of cereal crops up to 200-300 center-ha (Turusov et al., 2014).

In XIX century, the European scientists started discussions about the possibility of implementing the No-Till soil treatment system, at the beginning of XX century the scientific papers on this question were published in Russia. In the above scientific papers the possibility of guaranteed increasing of yield from 8 up to 80 centerha in the conditions of southern regions in Europaen part of Russia along with decreasing the labor and fund costs in four time and increasing soil fertility was presented (Ovsinsky, 1902). In the middle of XX century, the positive effect of No-Till teratment due to recovering the soil structure in the conditions of absence during the long period the intensive soil treatment was discussed in the scientific papers of Russian scientists (Maltsev, 1998). The activity of soil microorganisms causes the recovering of soil. The number of Russian and foreign scientists in the scientific paper presented the information about increasing the erosion processes and decreasing the humus content in soil in two times in many regions from the beginning to the $80^{\text {th }}$ of XX century. In the above conditions, only implementing the system of No-Till soil treatment allowed to decrease the degradation processes in soil. No-Till soil treatment started to be widely used in agrarian industry in the middle of XX century due to implementing of innovations and modem technical achievements (Baraev, 1978).

Launching the industrial implementing the system of No-Till soil treatment started in $1950^{\text {th }}$ from development of herbicides with wide weeding effect that allowed the farmers in the USA to deny using the plough and to sow without previous mouldboard ploughing. But, the herbicides are used not only in the system on No-Till soil treatment. In traditional ploughing system of soil management, the herbicides are used along with ploughing as the additional method of weeding in the postharvest period. In No-Till and resource saving system of soil management using the herbicides is considered as the "alter variant" for successful soil management. Modern technical and technological methods allow decreasing the costs during sowing, crop protection and harvesting. Within No-Till system of soil management, ploughing and cultivation are excluded that launches the initial mechanisms of regulating the soil parameters.

Sowing without the previous soil treatment is considered as denying the mouldboard ploughing, sowing into cutting resuides and conservation of residues in the field that is of high importance in the process of crop planting. The positive effects of the above soil treatment technology are the following: effective using the water; decreasing the erosion processes (up to 90\%); optimization of humus balance; preventing the formation of soil crust; increasing the work efficiency of machines and tools; sufficient water accumulation for sowing process; extending the period of production operations during the crop planting; stability of yield level; extending the service period of machines and aggregates; decreasing the labor costs; decreasing, in comparison with traditional ploughing, the number of machines and tools at $40 \%$ and gasoline consumption; increasing the economic efficiency at 25-20\% (Penn State Cooperative Extension, 2016).

No-Till system of soil management, as one of agrotechnical methods of year-round soil protection from erosion processes and decreasing the costs of sowing (planting) process, was successfully implemented in $1950^{\text {th }}$ in the USA. No-Till system is the alternative for traditional ploughing, which causes the wind and water soil erosion, and used at almost $40 \%$ of arable lands in the USA (Unger, 2002).

Many scientists from the Central Europe mention such positive ecological and economic effects of using not traditional systems of soil management as saving energy and labor costs, decreasing pollution and production costs. Using No-Till treatment destroys the soil structure in the minimum degree and includes the other methods of weeding except mechanical soil treatment. No-Till system of soil treatment restricts the infiltration rate especially in the regions with low precipitation level. Organic matter on the surface of field absorbs the major amount of precipitations which slowly migrate in the down level of soil (Atkinson et al., 2007).

In some drought regions of Pakistan on sandy loam soil the positive tillage effect on the yield of wheat in comparison with Mini-Till was observed. The soil treatment was based on the mouldboard ploughing. The above soil treatment technology is both gasoline and labor consuming and ecologically unfavorable. It is defined that $55-65 \%$ of gasoline is consumed during the operations on deep soil treatment (Ishaq et al., 2001).

In accordance with data of Food and Agricultural Organization of the United Nations No-Till system of soil treatment is used on the area of above 7,5 mln ha over the word, including 52\% - in the USA and Canada, 44\% - in Latin America, 2\% - in Australia, 2\% - the other countries in Europe and Africa. The potential for extending the area of soil under resource saving treatment should be realized along with the consideration of climatic and economic factors. As the example, in the USA possess 19,7\% of arable land, but the area 
treated with No -Till soil system in the country is the biggest in the world. In Paraguay the area under No-Till system of soil treatment is about $60 \%$.of arable lands. In China the rate of extending the area under No-Till soil treatment is rather significant. Nowadays in China No-Till system of soil treatment is used on above 300 thousand ha in 10 northern provinces. In accordance with the forecast of the Ministry of Agriculture of the People's Republic of China in the period of 7 - 10 years No-Till soil treatment will be used over the majority of arable lands in the northern part of the country. Many authors present in the papers the results of the positive ecological and economic effect from using the soil treatment without ploughing, e.g. energy and labor saving, decreasing pollution and costs. By the way, nowadays in Croatia 93,7\% of arable land are under tillage soil treatment (Jiang et al., 2005).

Nowadays No-Till system of soil treatment with the aim of soil protection and costs saving is widely used in the USA, countries of Western Europe and Latin America, Australia and other regions. In Russia the tendency of using the resource saving technologies of soil treatment is extending.

\section{Conclusion}

In Russia the design of field and industrial experiments on effectiveness of the different soil treatment systems should be renovated due to development and the usage of innovative machines and tools in industrial agrarian enterprises and small farms. On the results of long-term experiments, the effectiveness of combined soil treatment in field crops rotation of different climatic zones of the Russian Federation is defined.

\section{References}

Atkinson, R.S., Sparkes, D.L., Mooney, S.J., 2007. Using selected soil physical properties of seedbeds to predict crop establishment. Soil and Tillage Research 97(2): 218-228.

Balabanov, V.I., Zhelezova, S.V., Berezovsky, E.V., Belenkov, A.I., Egorov, V.V., 2013. Navigation systems in agriculture. Precision farming. Russian State Agrarian University - Moscow Timiryazev Agricultural Academy, Moscow, p. 148. [in Russian]

Baraev, A.I., 1978. Theoretical basis of protective soil management/Problems of soil management. Kolos, Moscow, pp. 212 - 220. [in Russian]

Belenkov, A.I., 2010. Crops rotation and soil treatment in steppe and semiarid zone of Nighnee Povojgye region. Monography, Moscow, p. 279. [in Russian]

Belenkov, A.I., 2015. Principles of resource saving in protective soil management/Protective soil management in Russia. Kursk Research Institute of Soil Management and Erosion Protection, pp. 77 - 81. [in Russian]

Belenkov, A.I., Shevchenko, V.A., Trofimova, T.A., Shachnev, V.P., 2015. Scientific and practical basis for development of soil treatment methods in modern adaptive land scape soil management systems. Russian State Agrarian University - Moscow Timiryazev Agricultural Academy, Moscow, p. 500. [in Russian]

Cherkasov, G.N., 2006. Effectiveness of combined soil treatment systems. Soil Management (6): 20 - 22. [in Russian]

Ishaq, M., Ibrahim, M., Lal, R., 2001. Tillage effect on nutrient uptake by wheat and cotton as influenced by fertilizer rate, Soil and Tillage Research 62 (1-2): 41-53.

Jiang, X., Li, Z., Hou, L., Wang, Y., Wang, X., Yan, H., 2005. Impacts of minimum tillage and no-tillage systems on soil NO-3$\mathrm{N}$ content and water use efficiency of winter wheat/summer corn cultivation. Transactions of the Chinese Society of Agricultural Engineering (CSAE) 21(7): 20-24.

Keller K., 2001 Soil management without plough: scientific achievements and practical experience in Western Europe and other regions. Achievements of Science and Technology of Agro-Industrial Complex (AIC) 11: 47 [in Russian]

Maltsev, T.S., 1988. Soil management system without ploughing. Agropromizdat, Moscow, p. 127. [in Russian]

Ovsinsky, I.E., 1902. New soil management system. St.-Petersburg, p. 325 [in Russian]

Penn State Cooperative Extension, 2016. The Penn State Agronomy Guide. Available at [Access date : 05.03.2016]: http://www.extension.psu.edu/agronomy-guide/cm/sec1/sec11f

Pleskachev, Yu. N., Koscheev, I.A., Kondybin, S.S., 2013. Tillage effect on yield of cereal crops. Proceeding of Altay State Agrarian University 1 (99): 23 - 26. [in Russian]

Sdobnikov, S.S., 2000. Soil treatment and soil fertility: to till or not to till. Moscow, p. 28 [in Russian]

Sheptukhov, V.N., 2006. Mechanical soil treatment and formation of crop roots level of soil. Moscow, p. 168. [in Russian]

Shulmeister, K.G., 1995. Selected works. Volgograd, Vol.1. p. 456, Vol. 2. P480. [in Russian]

Sukhov, A.N., Imangaliev, K.A., Imangalieva, A.K., 2011. Agroecological basis of field crops rotation and soil treatment in adaptive and land scape soil management systems in steppe and semiarid zone of Nighnee Povojgye region. Monography. Volgograd State Agrarian Academy, Volgograd, p. 192. [in Russian]

Turusov, V.I., Garmashov, V.M., Shevchenko, V.A., Dudchenko, S.E., 2014. The possibilities for Mini-Till system of soil management on black soils of Voronegh region. Acievements of Science and Technology of Agro-Industrial Complex (AIC) (12): 5 - 8. [in Russian]

Unger, P.W., 2002. Residue management for winter wheat and grain sorghum production with limited irrigation. Soil Science Society of America Journal 58(2): 537-542. 